\title{
Modulation of Human Immune Response by Fungal Biocontrol Agents
}

\author{
Cibele Konstantinovas ${ }^{1 \dagger}$, Tiago A. de Oliveira Mendes ${ }^{2 \dagger}$, Marcos A. Vannier-Santos ${ }^{3+}$ and \\ Jane Lima-Santos ${ }^{1 * t}$ \\ ${ }^{1}$ Departamento de Ciências Biológicas, Universidade Estadual de Santa Cruz, Ilhéus, Brazil, ${ }^{2}$ Departamento de Bioquímica e \\ Biologia Molecular, Universidade Federal de Viçosa, Viçosa, Brazil, ${ }^{3}$ Biologia Celular Parasitária, Instituto Gonçalo Moniz, \\ Fundação Oswaldo Cruz, Salvador, Brazil
}

\section{OPEN ACCESS}

Edited by:

Helio K. Takahashi,

Federal University of São Paulo, Brazil

Reviewed by:

Birinchi Kumar Sarma,

Banaras Hindu University, India

Rodrigo Tinoco Figueiredo,

Federal University of Rio de Janeiro,

Brazil

*Correspondence:

Jane Lima-Santos

jlsantos@uesc.br

${ }^{\dagger}$ These authors have contributed equally to this work.

Specialty section: This article was submitted to Fungi and Their Interactions,

a section of the journal

Frontiers in Microbiology

Received: 05 August 2016 Accepted: 06 January 2017 Published: 03 February 2017

Citation:

Konstantinovas C, de Oliveira Mendes TA, Vannier-Santos MA and Lima-Santos J (2017) Modulation of Human Immune Response by Fungal Biocontrol Agents.

Front. Microbiol. 8:39 doi: 10.3389/fmicb.2017.00039
Although the vast majority of biological control agents is generally regarded as safe for humans and environment, the increased exposure of agriculture workers, and consumer population to fungal substances may affect the immune system. Those compounds may be associated with both intense stimulation, resulting in lgE-mediated allergy and immune downmodulation induced by molecules such as cyclosporin A and mycotoxins. This review discusses the potential effects of biocontrol fungal components on human immune responses, possibly associated to infectious, inflammatory diseases, and defective defenses.

Keywords: spores, biofungicide, immunomodulation, biological control

\section{INTRODUCTION}

Phytopathogenic microorganisms are related to infestation of several crops resulting in economic losses. The Peruvian fungal-like oomycete Phytophtora infestans a potato pathogen caused the Irish famine and diaspora in the XIX century (Abad and Abad, 1997; Axel et al., 2012; Yoshida et al., 2013). More recently, in Bahia-Brazil, the fungus Moniliophtora perniciosa, etiological agent of witch's broom, caused extensive economic losses in cocoa crops (Meinhardt et al., 2008; Teixeira et al., 2015). The Trichoderma stromaticum spores comprise effective biocontrol agent for $M$. perniciosa (de Souza et al., 2006). Although most microbiological control agents are generally recognized as safe to humans and environment (Wang et al., 2004; Mommaerts et al., 2009), some studies demonstrated that those agents imbalance mammalian immune system leading to diseases such as allergy (Halpin et al., 1994). Given the socioeconomic impact of monocultures (Roossinck and García-Arenal, 2015), infections and the environmental hazards of chemical pesticides, biocontrol agents emerge as a strategic option and their increased use may cause higher exposure of cocoa workers. Moreover, the high fungal persistence in the environment (Scheepmaker and Butt, 2010), mainly spores (Darbro and Thomas, 2009), potentially causes exposures of consumer population to fungal substances. Here, we review the eventual mammalian immunological interactions triggered by fungal components and the association with infective and inflammatory diseases.

\section{AGRICULTURAL BIOCONTROL AGENT}

Biopesticides comprise more selective activity against pests whereas chemical pesticides are associated to pest resistance induction, requiring more applications, and residual toxic 
effects (Berg, 2009). The multiple modes of action of most microbial biocontrol agents cause reduced resistance selection by pathogens, insects, or weeds (Gardener and Fravel, 2002; Alabouvette et al., 2006). The ability of biocontrol agents to grow and reproduce, surviving for prolonged periods in the environment generally in symbiotic consortia with hosts, contributes to applications of lower bioagent amounts (Whipps, 2001). The decreased residual effect of biocontrol agents compared to chemical pesticides is also related of effective agents employing small quantities diminishing environment exposure (Thakore, 2006; Gupta and Dikshit, 2010). Moreover, these biological agents, take part of the ecosystem, reducing the impact of their insertion in microbial community (Vázquez et al., 2000; Tahat et al., 2010).

The biocontrol agents are classified as microbial and biochemical pesticides (FAO, 1988). Microbial agents encompass viruses or live bacteria, fungi, and protists (Chandler et al., 2011). Biocontrol microbial agents may undergo different genetic modifications to optimize their biopesticide activity (Chet and Inbar, 1994; St Leger and Wang, 2010; Kowsari et al., 2014). On the other hand, biochemical agents are characterized by nonlive parts of microbes such as single molecules or mixtures with pesticide activity, including enzymes, and other macromolecules (Chavan and Deshpande, 2013), hormones (Martínez-Medina et al., 2014), and metabolites (Degenkolb and Vilcinskas, 2016).

Around 135 products are commercialized worldwide as biocontrol agents (Chandler et al., 2011), including products from 13 fungi. Some fungal biopesticide species are summarized on Table 1. These species display variable pesticide action modes including parasitism of plant-infecting nematodes by Paecilomyces genus (Cabanillas and Barker, 1989; Castillo Lopez et al., 2014), colonization of insect's body cavities by several Hypocreales species from Ascomycota causing the host death (Tartar et al., 2005), environmental competition, parasitism with others undesirable fungi, and stimulation of defense mechanisms of plants by Trichoderma genus (Benítez et al., 2004). In addition, several fungal endophytic species colonize internal plant tissues, stimulating an important host defense mechanisms against pathogens (Wani et al., 2015). Some fungal species show a strong specificity for plant host, but analysis of host-specificity is complex and misleading because in vitro experiments do not completely simulate the natural environments (Stoeva et al., 2012). Furthermore, this organism group presents significant potential impact on the human and animal health due to propagation of spores adapted to dispersion for resisting harsh environmental conditions (Baxi et al., 2016).

\section{BIOCONTROL AGENTS AND HUMAN HEALTH}

Although fungal biocontrol pose numerous benefits, these agents can survive and reproduce in the environment, and so they are aspirated or swallowed by humans or other animals (Hansen et al., 2010; Luangsa-Ard et al., 2011). The increased exposure to fungi or fungal molecules may affect human health (Eduard et al., 2001). For instance, it is known that some fungi used as biocontrol agents can compromise the respiratory tracts of mammals (Madsen et al., 2007). Infections by biocontrol agents, considered opportunistic pathogens are common in immunocompromised patients, mainly submitted to immunosuppressive therapy such as organ transplant recipients. Disorders such as sinusitis and pulmonary lesions caused by $T$. longibrachiatum and T. harzianum were reported in intestine, liver and bone marrow transplant recipients especially in neutropenic patients (Furukawa et al., 1998; Guarro et al., 1999; Richter et al., 1999). T. longibrachiatum is the most common species involved in Trichoderma infections (Trabelsi et al., 2010) and its virulence factors include mycelial growth at $37^{\circ} \mathrm{C}$ and physiological $\mathrm{pH}$, hemolytic activity and toxicity to mammalian cells (Antal et al., 2005), extracellular protease(s) (Kredics et al., 2004) as well as resistance to antifungal compounds such as fluconazole, itraconazole, and amphotericin B (Singh et al., 1997; Richter et al., 1999; Espinel-Ingroff, 2001; Dóczi et al., 2004). Nevertheless, T. longibrachiatum was detected in sphenoidal sinus infection in immunocompetent patient, only displaying eosinophilia (Molnár-Gábor et al., 2013). Experimental models with rodents are used to measure potential effects such as allergenicity, toxicity, infectivity, and pathogenicity, in order to evaluate biofungicide safety (US Environmental Protection Agency (EPA), 1996).

Methods presented in the protocol of The Microbial Pesticide Test Guidelines of the Environmental Protection Agency of the USA (US Environmental Protection Agency (EPA), 1996) that evaluate risks to humans and domestic animals are carried out using live microorganisms such as Bacillus thuringiensis var israelensis SH-14 in rats, Beauveria bassiana, and Paecilomyces fumosoroseus in mice (Mier et al., 2005; Zimmermann, 2007; Mancebo et al., 2011). Despite the rigorous risk assessment protocol, epidemiologic studies have previously demonstrated the correlation of exposure to fungal organisms and frequency of diseases. For instance, the increased exposure to spores and mycotoxins from Cladosporium species affects alveolar type II cells, macrophages, and pulmonary surfactant production and composition (Kuhn and Ghannoum, 2003). Human cells exposure to Cladosporium extracts in vitro induces cytokines of Th1 and Th2-type Thelper cell and eosinophils migration (Shin et al., 2004). The exposure to 1500 Cladosporium spores $/ \mathrm{m}^{3}$ reduced lung function in schoolchildren and the changes appear to be associated with the small size of the spores that are deposited in the human lower respiratory tract, and to Cladosporium allergens (Chen et al., 2014). Among 389 patients with suspected respiratory allergy and exposure to T. harzianum (Das and Gupta-Bhattacharya, 2009), 105 showed positive skin reaction against $T$. harzianum extract and IgE specific to fungal proteins.

\section{BIOCONTROL AGENTS AND IMMUNE SYSTEM HOMEOSTASIS}

Exposure to high concentrations of environmental fungal spores can cause human disorders such as allergies and toxic mold syndrome (Edmondson et al., 2005; Eduard, 2009). In 
TABLE 1 | Immunomodulatory biomolecules in biocontrol fungal.

\begin{tabular}{|c|c|c|c|c|}
\hline Specie fungal biocontrol & Phytopathogen & Crop & $\begin{array}{l}\text { Immunomodulatory } \\
\text { biomolecules }\end{array}$ & References \\
\hline Beauveria bassiana & $\begin{array}{l}\text { Bemisia tabaci Hedypathes } \\
\text { betulinus Tetranychus urticae }\end{array}$ & $\begin{array}{l}\text { Chrysanthemum, citrus, horticulture, } \\
\text { cucumber; Eucalyptus, papaya, coffee, } \\
\text { soybean }\end{array}$ & & Tartar et al., 2005 \\
\hline Cladosporium sp. & $\begin{array}{l}\text { Uromyces appenciculatus } \\
\text { Cronartium flaccidum } \\
\text { Peridermium pini }\end{array}$ & Beans, coffee, rice & $\beta$-glucan & Van Dyken et al., 2011 \\
\hline Paecilomyces sp. & $\begin{array}{l}\text { Citrus psyllid Spider mite, } \\
\text { Thrips, Whitefly }\end{array}$ & $\begin{array}{l}\text { Apples and stonefruits, citrus, grapes, tree } \\
\text { nuts, strawberries, melons, cucurbits, herbs, } \\
\text { spices, beans }\end{array}$ & & $\begin{array}{l}\text { Cabanillas and Barker, } \\
\text { 1989; Castillo Lopez et al., } \\
2014\end{array}$ \\
\hline $\begin{array}{l}\text { Trichoderma polysporum } \\
\text { Trichoderma harzianum }\end{array}$ & $\begin{array}{l}\text { Fusarium, Phytopthara, } \\
\text { Scelerotia, }\end{array}$ & $\begin{array}{l}\text { Vegetables, fruits and berries herbs and } \\
\text { spices, ornamentals, Turf, forestry }\end{array}$ & Ciclosporin A & $\begin{array}{l}\text { Dreyfuss et al., 1976; } \\
\text { Benítez et al., 2004; Azam } \\
\text { et al., } 2012\end{array}$ \\
\hline Trichoderma harzianum & $\begin{array}{l}\text { Sclerotina, Fusarium, } \\
\text { Rhizoctonia }\end{array}$ & $\begin{array}{l}\text { Bean, soy, corn, strawberry, vegetables, } \\
\text { ornamentals }\end{array}$ & Gliovirin & $\begin{array}{l}\text { Benítez et al., 2004; Rether } \\
\text { et al., } 2007\end{array}$ \\
\hline Trichoderma viride & $\begin{array}{l}\text { Sclerotium rolfsii, Rhizoctonia } \\
\text { solani, Pythium spp. }\end{array}$ & $\begin{array}{l}\text { Sweet potato, pumpkin, corn, wheat, peanut, } \\
\text { Soybean seed, cotton seedlings and } \\
\text { Horticultural crops }\end{array}$ & Gliotoxin & $\begin{array}{l}\text { Brian and Hemming, 1945; } \\
\text { Lumsden et al., 1992; } \\
\text { Benítez et al., 2004; } \\
\text { Becker et al., } 2016\end{array}$ \\
\hline Trichoderma stromaticum & Moniliophthora perniciosa & Cacao & Spores & $\begin{array}{l}\text { de Souza et al., 2006; } \\
\text { Alves-Filho et al., } 2011\end{array}$ \\
\hline
\end{tabular}

agriculture, the application of biocontrol products containing microbiological pest control agents (MPCAs) can increase the exposure of workers to microbial agents (Hansen et al., 2010). The exposure to indoor fungal spores and humidity seem to be associated with an increased risk of asthma morbidity in young children as well as people who have previously suffered asthmatic attack (Baxi et al., 2016). Nevertheless, the importance of exposure time, the potential of different fungal species and molecular components responsible for damage and symptoms are still unknown. A common mechanism associated with allergy triggered by biocontrol agents such as B. bassiana (Westwood et al., 2005, 2006), Metarhizium anisopliae (Ward et al., 2011), Paecilomyces and Trichoderma viride (Beezhold et al., 2008), and Penicillium oxalicum (Kochar et al., 2014) is the production of IgE against fungal molecules observed in animal models and human patients.

In contrast to immune response exacerbation due to stimulation of IgE production by common fungal allergens, a few studies demonstrated that biocontrol agents can impair immune system homeostasis through negative modulation. Mice exposed to intranasal T. stromaticum spores employed in ex vivo assays for cytokine measurements, revealed diminished IL-10 and IFN$\gamma$ levels in bronchoalveolar lavage fluid and splenocyte cultures (Alves-Filho et al., 2011). Besides that, phagocytes obtained from thioglycolate-treated mice, exposed to T. stromaticum spores in vitro showed downregulated production of nitric oxide (NO) by inducible nitric oxide synthase (iNOS) and reactive oxygen species (ROS) by neutrophils. In addition, both cell types display decreased expression of Clec7a gene that codes the Dectin-1 receptor, Toll Like Receptor 2 (Tlr2), and Toll Like Receptor 4 (Tlr4). Hence, the in vitro and in vivo experiments carried out with T. stromaticum suggested a possible negative modulation mainly of the cell components of the murine innate immune system.

Some molecules from biocontrol fungal agents, that act during the mycoparasitism or stimulating the defense mechanisms of the host plant, have been previously identified as modulators of the mammalian immune response (Table 1). For instance, Cylindrocapon lucidum, Trichoderma polysporum currently identified as Tolypocladium inflatum, Fusarium oxysporum, and T. harzianun fungi produce cyclosporin A (CsA) (Dreyfuss et al., 1976; Rodríguez et al., 2006; Azam et al., 2012). This molecule is considered a virulence factor for including its antifungal activity against the phytopathogen $M$. perniciosa, and one of its intracellular targets is cyclophilin protein. CsA activity assays over the pathogen $M$. perniciosa demonstrated inhibition of basidiospore germination and mycelium growth in vitro (Monzani et al., 2011). On the other hand, the immunomodulatory function of CsA, due to its well-established capacity to inhibit calcineurin, is associated to impaired activity of the nuclear factor of activated T cells (NFAT) and reduced activation, proliferation, and survival of lymphoid cells (Rovira et al., 2000). This immunosuppressant action of CsA is interesting because of its potential use for preventing acute rejection in organ transplantation (Borel et al., 1976; Levy, 2001). Another important action mechanism of CsA consists of inhibition of NO production by destabilization of the iNOS mRNA (Hämäläinen et al., 2009). Furthermore, CsA downregulate the signaling pathway of the NFкb transcription factor through the inhibition of TLR4 expression (Dusting et al., 1999; Rovira et al., 2000; Ge et al., 2012). The impact of CsA from environmental fungi in human health remains inconclusive since it is detected in crops such as maize (Mogensen et al., 2011), but the molecule displays slow and incomplete oral absorption 
(Ptachcinski et al., 1986). Detailed studies are required to clarify whether cyclosporin A produced by biocontrol fungi accumulate in cultures and if the consumption of these cultures comprises risks to the homeostasis of the human immune system.

In addition to cyclosporin, peptaibiotics, siderophores, and epidithiodioxopiperazine (ETPs) make up the group of secondary metabolites named non-ribosomal peptides (NRPs) and, the success of Trichoderma species as biocontrol agent is at least in part due to the ability of these fungi to produce these biotechnology relevant metabolites (Zeilinger et al., 2016). Particularly the toxicity of the ETPs gliovirin and gliotoxin is due to the eventual inactivation of proteins by interaction of their disulfide bridges to thiol groups (Gardiner et al., 2005). In mammals, modulation of the immune response by gliovirin is related to decreased expression of tumor necrosis factor in consequence of inhibition of the AP1 and NFkb-factors transcription (Rether et al., 2007). In addition, gliotoxin, a well-studied metabolite, inhibits several mechanisms of innate immunity including phagocytosis, activation of the NADPH oxidase complex responsible for the generation of ROS and NFKB nuclear factor, indispensable for the production of cytokines and reactive nitrogen species such as nitric oxide (Figure 1; Lumsden et al., 1992).

Gliotoxin was firstly identified in Trichoderma virens (Brian and Hemming, 1945; Lumsden et al., 1992) and is produced by several fungal species (Scharf et al., 2016). This molecule showed antibiotic activity against plant pathogens such as Rhizoctonia solani, Pythium ultimum, Sclerotinia sclerotiorum (Vargas et al., 2014), and Botrytes cinerea (Lorito et al., 1994). The action mechanisms against phytopathogens include cytoplasmic material leakage (necrosis), inhibition of sporangia germination, and mycelial growth (Roberts and Lumsdem, 1990; Lorito et al., 1994; Lewis et al., 2005; Scharf et al., 2016).

Although there is little evidence of the involvement of gliotoxin in human disease, exposure to this toxin appears to occur during infections by pathogenic fungi such as Aspergillus fumigattus and Candida albicans, but evidence of immunosuppressive activity associated with intoxication due to fungal infection remains inconclusive (Bondy and Pestka, 2000). The antigen-presenting cells including thioglycolateelicited mouse peritoneal macrophages exposed to gliotoxin show inhibited phagocytosis and adhesion capacity (Müllbacher and Eichner, 1984). J774 cells and human macrophages differentiated from THP1 monocytes showed increased phagocytosis of $A$. fumigatus gliP $\Delta$ mutant conidia, a strain depleted of the gliP gene, responsible for the biosynthesis of gliotoxin, as compared to wild-type A. fumigatus conidia and conidia gliPR (reconstituted gliP). Both J774 and THP1 incubated with exogenous gliotoxin, display significantly reduced uptake of conidia of the three strains, indicating that the gliotoxin produced by A. fumigatus inhibits phagocytosis by macrophages (Jia et al., 2014). Low concentrations of gliotoxin $(30-100 \mathrm{ng} / \mathrm{mL})$ inhibit zymosan phagocytosis by human polymorphonuclear leukocytes. In addition, the compound induces neutrophil cell shrinkage, Factin collapse in the perinuclear region and disappearance of filopodia without affecting the protein polymerization process, but this reorganization does not seem to correlate with phagocytosis reduction (Coméra et al., 2007). Recently it has been shown that gliotoxin affects phagocytosis, a key macrophage function, modifying the homeostasis of phosphatidylinositol 3,4,5-trisphosphate and interfering in integrin activation and actin dynamics (Schlam et al., 2016; Figure 1).

This gliotoxin inhibits neutrophil ability to produce $\mathrm{O}_{2}^{\bullet-}$, especially when added prior to the activation of the NADPH oxidase by phorbol myristate acetate (PMA; Yoshida et al., 2000; Tsunawaki et al., 2004). This inhibition is a consequence of the reduction of translocation levels of cytosolic Phox components to membrane rather than of oxidase assembly (Tsunawaki et al., 2004; Figure 1). The immunoregulatory effects of gliotoxin on mononuclear cells are due at least in part, to their potential to block the degradation of the most abundant inhibitory subunit

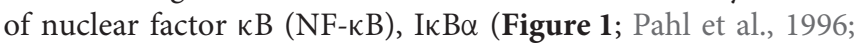
Kroll et al., 1999). Recently the high throughput screening (HTS) technique with Tb3+ -Fluorescein FRET was used to demonstrate that gliotoxin selectively binds at the catalytic center of the linear ubiquitin chain assembly complex (LUBAC) inhibiting ubiquitin chain formation and signal-induced $\mathrm{NF \kappa B}$ activation (Sakamoto et al., 2015). The reduction in IкB $\alpha$ degradation results in inhibition of cytoplasmic activation and nuclear translocation of NFKB in different cells. Gliotoxin induces negative modulation of pro-inflammatory cytokines associated with down-regulation of genes, which in turn are associated with inhibition of $\mathrm{NF \kappa B}$, and result in increased susceptibility to microorganisms (Kupfahl et al., 2006). In human monocyte cell lines, gliotoxin favors a cytokine imbalance with relevant inhibition of IL-10 production (Johannessen et al., 2005).

The detection and relevance of gliotoxin from biocontrol fungi to human health, particularly for occupationally exposed individuals were scarcely studied. There is no in-depth, bona fide knowledge regarding symptoms and doses that cause susceptibility in individuals and little is known about the presence of this toxin in bioaerosols. Studies determined a total of 0.22 microgram of gliotoxin in extract of $6.2 \times 10^{8}$ spores from Aspergillus fumigatus mechanically disintegrated (Schulz et al., 2004). The presence of gliotoxin has been described in biocontrol fungal species of the genus Trichoderma including T. viride and T. virens (Brian and Hemming, 1945; Anitha and Murugesan, 2005). Thus, inhalation of aerosols containing high concentrations of spores may comprise a potential health hazard.

Cell wall components such as chitin and $\beta$-glucan were identified in biocontrol fungi spores and are extensively studied during biocontrol-pathogen-plant interaction. These carbohydrate polymers may induce modulatory activity affecting the production of both pro-inflammatory and anti-inflammatory cytokines (Sorrell and Chen, 2009; Koller et al., 2011; Brodaczewska et al., 2015; Becker et al., 2016). Chitin a polymer of beta-(1,4)-linked $\mathrm{N}$-acetylglucosamine (GlcNAc) and $\beta$-glucan, glucose polymers linked together by1-3 linear $\beta$ glycosidic are pathogen-associated molecular patterns (PAMPs) able to modulate the innate immune response of various cells including monocytes, macrophages, neutrophils, and NK through of pattern recognition receptors (PRRs), including TLR-2 and C-Type Lectin Receptors (CLR) such as Dectin-1, Dectin-2, and Manose Receptor (Barreto-Bergter and Figueiredo, 


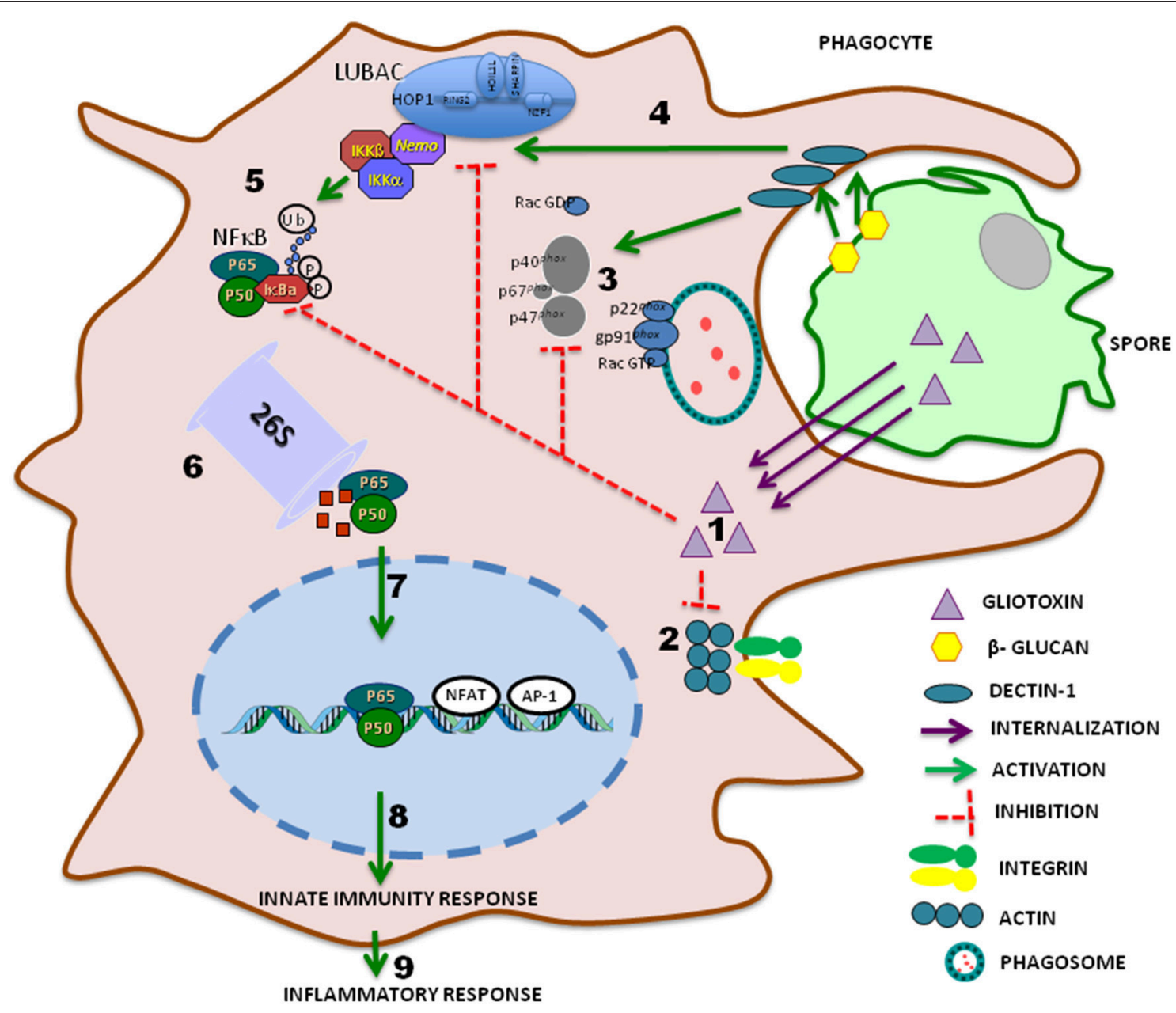

FIGURE 1 | Schematic representation of major phagocyte modulation pathway induced by gliotoxin from fungal: spore internalization by phagocytes is an essential mechanism to prevent hyphae formation by pathogenic fungi. Gliotoxin triggers (1) F-actin disorganization, inhibition of phagocytosis by deregulation of Ptdlns $(3,4,5) \mathrm{P} 3$ turnover, resulting in integrin and actin cytoskeleton dysfunction, preventing pseudopodia emission (2). Gliotoxin also blocks translocation of cytosolic phox proteins (p40, p67, p47) that bind to membrane proteins of phagolysosomes, gp91 and p22 to form NADPH oxidase, inhibiting reactive oxygen species (ROS) formation (3). Dectin-1-mediated ubiquitin chain formation (4) and NF-kB activity (5) are negatively modulated by gliotoxin.

Phosphorylation of $\mathrm{I} B_{\mathrm{B} \alpha}$ leads to its ubiquitination and proteasomal degradation (6). Active heterodimer p50-p65 is then released and translocated to the nucleus (7), binds to specific $\mathrm{\kappa B}$ sites and either alone or in combination with other transcription factors, activates NF-кB target gene expression of the innate (8) and inflammatory immune response (9).

2014; Brodaczewska et al., 2015). These interactions between PAMPs and specific PRRs upregulate innate responses and Th1 responses in humans and animals (Rop et al., 2009; Muzzarelli, 2010). However, chitin is able to induce the Th2 immune response, exacerbating allergic reactions (Gregory and Lloyd, 2011; Dubey et al., 2015). In addition, soluble $\beta$-glucan from Candida albicans reverses or impairs the activation of human monocytes cultured with endotoxin. This $\beta$-glucan effect is associated to the suppressed production of the type 1 cytokines IL-2 and IFN- $\gamma$ by cultured human PBMC (Nakagawa et al., 2003). The dual immunological effect de chitin and $\beta$-glucan is due at least in part to features such as particle size, tissue in which the contact with macrophage takes place, environmental cytokines and surface availability of spore $\beta$-glucans (Da Silva et al., 2009; Mintz-Cole et al., 2013; Alvarez, 2014). Furthermore, chitin induces accumulation of innate immune cells expressing IL-4 including eosinophils and basophils in tissue from mice and these events are associated with allergy (Reese et al., 2007). Specifically, fungal chitin from dust collected from the homes of asthmatic individuals, induces marked eosinophilic lung infiltration particularly whenever associated with $\beta$-glucans (Van Dyken et al., 2011).

As the structure of the fungal cell wall and the PAMPs exposed at the cell surface are genus-, species- and morphotypedependent (Brodaczewska et al., 2015), detailed studies on modulation of the mammals immune system induced by biocontrol agent spores and mycotoxins is relevant to medicine 
and biotechnology. The compromised immune system may favor the development of opportunistic pathogens (Fishman, 2011) and even neoplastic diseases (Barle et al., 2014). The immunosuppressive molecules may comprise chemotherapy agents for autoimmunity and hypersensitivity reactions (Thell et al., 2014). Although there is little research approaching the health effects of biocontrol fungi, the preliminary data indicate that the impact upon immune system can be more significant than previously supposed. Henceforth, further studies are required to identify the compounds of these fungi, accumulation during crop storage, amount ingested or inhaled by the consumer/worker, mechanisms associated with immune

\section{REFERENCES}

Alvarez, F. J. (2014). The effect of chitin size, shape, source and purification method on immune recognition. Molecules 19, 4433-4451. doi: 10.3390/molecules 19044433

Abad, Z. G., and Abad, J. A. (1997). Another look at the origin of late blight of potatoes, tomatoes, and pear melon in the Andes of South America. Plant Dis. 81, 682-688. doi: 10.1094/PDIS.1997.81.6.682

Alabouvette, C., Olivain, C., and Steinberg, C. (2006). Biological control of plant diseases: the European situation. Eur. J. Plant Pathol. 114, 329-341. doi: 10.1007/s10658-005-0233-0

Alves-Filho, E. R., Maioli, T. U., Faria, A. M., Noronha, F. S., Silva, N. M., Costa, M. G., et al. (2011). The biocontrol fungus Trichoderma stromaticum downregulates respiratory burst and nitric oxide in phagocytes and IFN-gamma and IL-10. J. Toxicol. Environ. Health A 74, 943-958. doi: 10.1080/15287394.2011573747.

Anitha, R., and Murugesan, K. (2005). Production of gliotoxin on natural substrates by Trichoderma virens. J. Basic Microbiol. 45, 12-19. doi: 10.1002/jobm.200410451

Antal, Z., Kredics, L., Pakarinen, J., Dóczi, I., Anderson, M., Salkinoja-Salonen, M., et al. (2005). Comparative study of potential virulence factors in human pathogenic and saprophytic Trichoderma longibrachiatum strains. Acta Microbiol. Immunol. Hung. 52, 341-350. doi: 10.1556/AMicr.52.2005.3-4.6

Axel, C., Zannini, E., Coffey, A., Guo, J., Waters, D. M., and Arendt, E. K. (2012). Ecofriendly control of potato late blight causative agent and the potential role of lactic acid bacteria: a review. Appl. Microbiol. Biotechnol. 96, 37-48. doi: 10.1007/s00253-012-4282-y

Azam, A., Anjum, T., and Irum, W. (2012). Trichoderma harzianum: a new fungal source for the production of cyclosporin A. Bangladesh J. Pharmacol. 7, 33-35. doi: 10.3329/bjp.v7i1.10084

Barle, E. L., Winkler, G. C., Ulrich, P., Perino, C., Kuster, M., Probst, A., et al. (2014). Cancer risk of immunosuppressants in manufacturing. Regul. Toxicol. Pharmacol. 70, 122-124. doi: 10.1016/j.yrtph.2014.06.025

Baxi, S. N., Portnoy, J. M., Larenas-Linnemann, D., Phipatanakul, W., and Environmental Allergens Workgroup (2016). Exposure and health effects of fungi on humans. J. Allergy Clin. Immunol. Pract. 4, 396-304. doi: 10.1016/j.jaip.2016.01.008

Becker, K. L., Aimanianda, V., Wang, X., Grensnigt, M. S., Ammerdorffer, A., Jacobs, C. W., et al. (2016). Aspergillus cell wall chitin induces anti- and proinflammatory cytokines in human PBMCs via the Fc- $\gamma$ receptors/Syk/PI3K phatway. MBio 7:e01823-15. doi: 10.1128/mBio.01823-15

Beezhold, D. H., Green, B. J., Blachere, F. M., Schemechel, D., Weissman, D. N., Velickoff, D., et al. (2008). Prevalence of allergic sensitization to indoor fungi in West Virginia. Allergy Asthma Proc. 29, 29-34. doi: 10.2500/aap2008.29.3076

Benítez, T., Rincón, A. M., Limón, M. C., and Codón, A. C. (2004). Biocontrol mechanisms of Trichoderma strains. Int. Microbiol. 7, 249-260.

Berg, G. (2009). Plant-microbe interactions promoting plant growth and health: perspectives for controlled use of microorganisms in agriculture. Appl. Microbiol. Biotechnol. 84, 11-18. doi: 10.1007/s00253-009-2092-7 modulation, eventual health hazards as well as potential biotechnological use of such compounds.

\section{AUTHOR CONTRIBUTIONS}

All authors listed, have made substantial, direct and intellectual contribution to the work, and approved it for publication.

\section{FUNDING}

This article was funded by a grant from Universidade Estadual de Santa Cruz-Brazil.

Barreto-Bergter, E., and Figueiredo, R. T. (2014). Fungal glycans and the innate immune recognition. Front. Cell Infect. Microbiol. 4:145. doi: $10.3389 /$ fcimb.2014.00145

Bondy, G. S., and Pestka, J. J. (2000). Immunomodulation by fungal toxins. J. Toxicol. Environ. Health B Crit. Rev. 3, 109-143. doi: 10.1080/109374000281113

Borel, J. F., Feurer, C., Gubler, H. U., and Stähelin, H. (1976). Biological effects of cyclosporin A: a new antilymphocyte agent. Agents Actions 6, 468-475. doi: 10.1007/BF01973261

Brian, P. W., and Hemming, H. G. (1945). Gliotoxin, a fungistatic metabolic product of Trichoderma viride. Ann. Appl. Biol. 32, 214-220. doi: 10.1111/j.1744-7348.1945.tb06238.x

Brodaczewska, K., Donkow-Lysoniewska, K., and Doligauska, M. (2015). Chitin, a key factor in immune regulation: lesson from infection with fungi and chitin bearing parasites. Acta Parasitol. 60, 337-344. doi: 10.1515/ap-2015-0047

Cabanillas, E., and Barker, K. R. (1989). Impact of Paecilomyces lilacinus inoculum level and application time on control of meloidogyne incognita on tomato. J. Nematol. 21, 115-120.

Castillo Lopez, D., Zhu-Salzman, K., Ek-Ramos, M. J., and Sword, G. A. (2014). The entomopathogenic fungal endophytes Purpureocillium lilacinum (formerly Paecilomyces lilacinus) and Beauveria bassiana negatively affect cotton aphid reproduction under both greenhouse and field conditions. PLoS ONE 9:e103891. doi: 10.1371/journal.pone.0103891

Chandler, D., Bailey, A. S., Tatchell, G. M., Davidson, G., Greaves, J., and Grant, W. P. (2011). The development, regulation and use of biopesticides for integrated pest management. Philos. Trans. R. Soc. Lond. B Biol. Sci. 366, 1987-1998. doi: $10.1098 /$ rstb.2010.0390

Chavan, S. B., and Deshpande, M. V. (2013). Chitinolytic enzymes: an appraisal as a product of commercial potential. Biotechnol. Prog. 29, 833-846. doi: 10.1002/btpr.1732

Chen, B. Y., Jasmine Chao, H., Wu, C. F., Kim, H., Honda, Y., and Guo, Y. L. (2014). High ambient Cladosporium spores were associated with reduced lung function in schoolchildren in a longitudinal study. Sci. Total Environ. 481, 370-376. doi: 10.1016/j.scitotenv.2014.01.078

Chet, I., and Inbar, J. (1994). Biological control of fungal pathogens. Appl. Biochem. Biotechnol. 48, 37-33. doi: 10.1007/BF02825358

Coméra, C., André, K., Laffitte, J., Collet, X., Galtier, P., and Maridonneau-Parini, I. (2007). Gliotoxin from Aspergillus fumigatus affects phagocytosis and the organization of the actin cytoskeleton by distinct signalling pathways in human neutrophils. Microbes Infect. 9, 47-54. doi: 10.1016/j.micinf.2006.10.009

Darbro, J. M., and Thomas, M. B. (2009). Spore persistence and likelihood of aeroallergenicity of entomopathogenic fungi used for mosquito control. Am. J. Trop. Med. Hyg. 80, 992-997.

Da Silva, C. A., Chalouni, C., Williams, A., Hartl, D., Lee, C. G., and Elias, J. Á. (2009). Chitin is a size-dependent regulator of macrophage TNF and IL-10 production. J Immunol. 182, 3573-3582. doi: 10.4049/jimmunol.08 02113

Das, S., and Gupta-Bhattacharya, S. (2009). Trichoderma harzianum: occurrence in the air and clinical significance. Aerobiologia 25, 137-145. doi: $10.1007 /$ s10453-009-9119-5 
Degenkolb, T., and Vilcinskas, A. (2016). Metabolites from namatophagous fungi and nematicidal natural products from fungi as an alternative for biological control. Part I: metabolites from nematophagous ascomycetes. Appl. Microbiol. Biotechnol. 100, 3799-3812. doi: 10.1007/s00253-015-7233-6

de Souza, J. T., Pomella, A. W., Bowers, J. H., Pirovani, C. P., Loguercio, L. L., and Hebbar, K. P. (2006). Genetic and biological diversity of Trichoderma stromaticum, a mycoparasite of the Cacao Witches'-Broom Pathogen. Phytopathology 96, 61-67. doi: 10.1094/PHYTO-96-0061

Dóczi, I., Dósa, E., Varga, J., Antal, Z., Kredics, L., and Nagy, E. (2004). Etest for assessing the susceptibility of filamentous fungi. Acta Microbiol. Immunol. Hung. 5, 271-281. doi: 10.1556/AMicr.51.2004.3.5

Dreyfuss, M., Härri, E., Hoffmann, H., Kobel, H., Pache, W., and Tscherter, H. (1976). Cyclosporin A and C. new metabolites from Trichoderma polysporum (Link ex. Pers.) Rifai. Eur. J. Appl. Microbiol. 3, 125-133.

Dubey, L. K., Moeller, J. B., Schlosser, A., Sorensen, G. L., and Holmskov, U. (2015). Chitin enhances serum IgE in Aspergillus fumigatus induced allergy in mice. Immunobiology 220, 714-721. doi: 10.1016/j.imbio.2015.01.002

Dusting, G. J., Akita, K., Hickey, H., Smith, M., and Gurevich, V. (1999). Cyclosporin, A., and tacrolimus (FK506) suppress expression of inducible nitric oxide synthase in vitro by different mechanisms. Br. J. Pharmacol. 128, 337-344. doi: 10.1038/sj.bjp.0702782

Edmondson, D. A., Nordness, M. E., Zacharisen, M. C., Kurup, V. P., and Fink, J. N. (2005). Allergy and "toxic mold syndrome". Ann. Allergy Asthma Immunol. 94, 234-239. doi: 10.1016/S1081-1206(10)61301-4

Eduard, W. (2009). Fungal spores: a critical review of the toxicological and epidemiological evidence as a basis for occupational exposure limit setting. Crit. Rev. Toxicol. 39, 799-764. doi: 10.3109/10408440903307333

Eduard, W., Douwes, J., Mehl, R., Heederik, D., and Melbostad, E. (2001). Short term exposure to airborne microbial agents during farm work: exposureresponse relations with eye and respiratory symptoms. Occup. Environ. Med. 58, 113-118. doi: $10.1136 /$ oem.58.2.113

Espinel-Ingroff, A. (2001). In vitro fungicidal activities of voriconazole, itraconazole, and amphotericin B against opportunistic moniliaceous and dematiaceous fungi. J. Clin. Microbiol. 39, 954-958. doi: 10.1128/JCM.39.3.954-958.2001

FAO. (1988). Guildness on the Registration of Biological Pest Control Agent. Rome: Food and Agriculture Organization of the United Nations.

Fishman, J. A. (2011). Infections in immunocompromised hosts and organ transplant recipients: essentials. Liver Transpl. 17, 34-37. doi: 10.1002/lt.22378

Furukawa, H., Kusne, S., Sutton, D. A., Manez, R., Carrau, R., Nichols, L., et al. (1998). Acute invasive sinusitis due to Trichoderma longibrachiatum in a liver and small bowel transplant recipient. Clin. Infect. Dis. 26, 487-489. doi: $10.1086 / 516317$

Gardener, M. B., and Fravel, D. R. (2002). Biological control of plant pathogens: research, commercialization and application in the USA. Plant Health Prog. doi: 10.1094/PHP-2002-0510-01-RV. [Epub ahead of print].

Gardiner, D. M., Waring, P., and Howlett, B. J. (2005). The epipolythiodioxopiperazine (ETP) class of fungal toxins: distribution, mode of action, functions and biosynthesis. Microbiology 151, 1021-1032. doi: 10.1099/mic.0.27847-0

Ge, Y., Xu, Y., Sun, W., Man, Z., Zhu, L., Xia, X., et al. (2012). The molecular mechanisms of the effect of Dexamethasone and Cyclosporin A on TLR4/NFkB signaling pathway activation in oral lichen planus. Gene 508, 157-164. doi: 10.1016/j.gene.2012.045.

Gregory, L. G., and Lloyd, C. M. (2011). Orchestrating house dust mite-associated allergy in the lung. Trends Immunol. 32, 402-411. doi: 10.1016/j.it.2011.06.006

Guarro, J., Antolín-Ayala, M. I., Gené, J., Gutiérrez-Calzada, J., Nieves-Díez, C., and Ortoneda, M. (1999). Fatal case of Trichoderma harzianum infection in a renal transplant recipient. J. Clin. Microbiol. 37, 3751-3755.

Gupta, S., and Dikshit, A. K. (2010). Biopesticides: an ecofriendly approach for pest control. J. Biopest. 3, 186-188.

Halpin, D. M., Graneek, B. J., Turner-Warwick, M., and Newman Taylor, A. J. (1994). Extrinsic allergic alveolitis and asthma in a sawmill worker: case report and review of the literature. Occup. Environ. Med. 51, 160-164. doi: 10.1136/oem.51.3.160

Hämäläinen, M., Korhonen, R., and Molianen, E. (2009). Calcineurin inhibitors down-regulate iNOS expression by destabilizing mRNA. Int. Immunopharmacol. 9, 159-167. doi: 10.1016/j.intimp.2008.07.012
Hansen, V. M., Winding, A., and Madsen, A. M. (2010). Exposure to bioaresols during the growth season of tomatoes in an organic greenhouse using supresivit (Trichoderma harzianum) and Mycostop (Streptomyces griseoviridis). Appl. Environ. Microbiol. 76, 5874-5881. doi: 10.1128/AEM.00446-10

Jia, X., Chen, F., Pan, W., Yu, R., Tian, S., Han, G., et al. (2014). Gliotoxin promotes Aspergillus fumigates internalization into type II human pneumocyte A549 cells by inducing host phospholipase D activation. Microbes Infect. 16, 491-501. doi: 10.1016/j.micinf.2014.03.001

Johannessen, L. N., Nilsen, A. M., and Løvik, M. (2005). The mycotoxins citrinin and gliotoxin differentially affect production of the pro-inflammatory cytokines tumour necrosis factor-alpha and interleukin-6, and the antiinflammatory cytokine interleukin-10. Clin. Exp. Allergy 35, 782-789. doi: 10.1111/j.1365-2222.2005.02249.x

Kochar, S., Ahlawat, M., Dahiya, P., and Chaudhary, D. (2014). Assessment of allergenicity to fungal allergens of Rohtak city, Haryana, India. Allergy Rhinol. 5, 56-65. doi: 10.2500/ar.2014.5.0088

Koller, B., Müller-Wiefel, A. S., Rupec, R., Korting, H. C., and Ruzicka, T. (2011). Chitin modulates innate immune responses of keratinocytes. PLoS ONE 6:e16594. doi: 10.1371/journal.pone.0016594

Kowsari, M., Motallebi, M., and Zamani, M. (2014). Protein engineering of chit42 towards improvement of chitinase and antifungal activities. Curr. Microbiol. 68, 495-402. doi: 10.1007/s00284-013-0494-3

Kredics, L., Antal, Z., Szekeres, A., Manczinger, L., Dóczi, I., Kevei, F., et al. (2004). Production of extracellular proteases by human pathogenic Trichoderma longibrachiatum strains. Acta Microbiol. Immunol. Hung. 51, 283-295. doi: 10.1556/AMicr.51.2004.3.6

Kroll, M., Arenzana-Seisdedos, F., Bachelerie, F., Thomas, D., Friguet, B., and Conconi, M. (1999). The secondary fungal metabolite gliotoxin targets proteolytic activities of the proteasome. Chem. Biol. 6, 689-698. doi: 10.1016/S1074-5521(00)80016-2

Kuhn, D. M., and Ghannoum, M. A. (2003). Indoor mold, toxigenic fungi, and stachybotrys chartarum: infectious disease perspective. Clin. Microbiol. Rev. 16, 144-172. doi: 10.1128/CMR.16.1.144-172.2003

Kupfahl, C., Geginat, G., and Hof, H. (2006). Gliotoxin-mediated suppression of innate and adaptative immune functions directed against Listeria monocytogens. Med. Mycol. 44, 591-599. doi: 10.1080/13693780600815411

Levy, G. A. (2001). Long-term immunosuppression and drug interactions. Liver Transpl. 7(11 Suppl. 1), S53-S59. doi: 10.1053/jlts.2001.28512

Lewis, R. E., Wiederhold, N. P., Lionakis, M. S., Prince, R. A., and Kontoyiannis, D. P. (2005). Frequncy and species distribuition of gliotoxin-producing Aspergillus isolates recovered from patients at a tertiary-care cancer center. J. Clin. Microbiol. 43, 6120-6122. doi: 10.1128/JCM.43.12.6120-612 2.2005

Lorito, M., Peterbauer, C., Hayes, C. K., and Harman, G. E. (1994). Synergistic interaction between fungal cell wall degrading enzymes and different antifungal compounds enhances inhibition of spore germination. Microbiology 140, 623-629. doi: 10.1099/00221287-140-3-623

Luangsa-Ard, J., Houbraken, J., van Doorn, T., Hong, S. B., Borman, A. M., Hywel-Jones, N. L., et al. (2011). Purpureocillium, a new genus for the medically important Paecilomyces lilacinus. FEMS Microbiol Lett. 321, 141-149. doi: 10.1111/j.1574-6968.2011.02322.x

Lumsden, R. D., Locke, J. C., Adkins, S. T., Walter, J. F., and Ridout, C. J. (1992). Isolation and localization of the antibiotic gliotoxin produced by Gliocladium virens from alginate prill in soil and soilless media. Phytopathology 82, 230-235. doi: 10.1094/Phyto-82-230

Madsen, A. M., Hansen, V. M., Meyling, N. V., and Eilemberg, J. (2007). Human exposure to airborne fungi from genera used as biocontrol agents in plant production. Ann. Agric. Environ. Med. 14, 5-24.

Mancebo, A., Molier, T., González, B., Lugo, S., Riera, L., Arteaga, M. E., et al. (2011). Acute oral, pulmonary and intravenous toxicity/pathogenicity testing of a new formulation of Bacillus thuringiensis var israelensis SH 14 in rats. Regul. Toxicol. Pharmacol. 59, 184-190. doi: 10.1016/j.yrtph.2010.10.003

Martínez-Medina, A., Del Mar Alguacil, M., Pascual, J. A., and Van Wees, S. C. (2014). Phytohormone profiles induced by trichoderma isolates correspond with their biocontrol and plant growth-promoting activity on melon plants. $J$. Chem. Ecol. 40, 804-815. doi: 10.1007/s10886-014-0478-1

Meinhardt, L. W., Rincones, J., Bailey, B. A., Aime, M. C., Griffith, G. W., Zhang, D., et al. (2008). Moniliophthora perniciosa, the causal agente of witches' broom 
disease of cacao: what's new from this old foe? Mol. Plant Pathol. 9, 577-588. doi: 10.1111/j.1364-3703.2008.00496.x

Mier, T., Olivares-Redonda, G., Navarro-Barranco, H., Pérez-Mejía, A., Lorenzana, M., Pérez-Torres, A., et al. (2005). Acute oral intragastric pathogenicity and toxicity in mice of paecilomyces fumosoroseus isolated from whiteflies. Antonie Van Leeuwenhoek 88, 103-111. doi: 10.1007/s10482-005-2016-1

Mintz-Cole, R. A., Brandt, E. B., Bass, S. A., Gibson, A. M., Reponen, T., and Khurana Hershey, G. K. (2013). Surface availability of beta-glucans is critical determinant of host immune response to Cladosporium cladosporioides. J. Allergy Clin. Immunol. 132, 159-169. doi: 10.1016/j.jaci.2013.01.003

Mogensen, J. M., Sørensen, S. M., Sulyok, M., van der Westhuizen, L., Shephard, G. S., Frisvad, J. C., et al. (2011). Single-kernel analysis of fumonisins and other fungal metabolites in maize from South African subsistence farmers. Food Addit. Contam. Part A Chem. Anal. Control Expo. Risk Assess. 28, 1724-1734. doi: 10.1080/19440049.2011.611823

Molnár-Gábor, E., Dóczi, I., Hatvani, L., Vágvölgyi, C., and Kredics, L. (2013). Isolated sinusitis sphenoidalis caused by Trichoderma longibrachiatum in an immunocompetent patient with headache. J. Med. Microbiol. 62, 1249-1252. doi: 10.1099/jmm.0.059485-0

Mommaerts, V., Sterk, G., Hoffmann, L., and Smagghe, G. (2009). A Laboratory evaluation to determine the compatibility of microbiological control agents with the pollinator Bombus terrestris. Pest Manage. Sci. 65, 949-955. doi: $10.1002 /$ ps. 1778

Monzani, P. S., Pereira, H. M., Gramacho, K. P., Alvim, F. C., Meirelles, F. V., Oliva, G., et al. (2011). Structural analysis of cyclophilin from Moniliophthora Perniciosa and inhibitory activity of cyclosporin an on germination and growth of fungi. Pharm. Anal. Acta. S7:001. doi: 10.4172/2153-2435.S7-001

Müllbacher, A., and Eichner, R. D. (1984). Immunosuppression in vitro by a metabolite of a human pathogenic fungus. Proc. Natl. Acad. Sci. U.S.A. 81, 3835-3837. doi: $10.1073 /$ pnas.81.12.3835

Muzzarelli, R. A. (2010). Chitins and chitosans as immunoadjuvants and nonallergenic drug carriers. Mar. Drugs 8, 292-312. doi: 10.3390/md8020292

Nakagawa, Y., Ohno, N., and Murai, T. (2003). Suppression by Candida albicans b-glucan of cytokine release from activated human monocytes and from $\mathrm{T}$ cells in the presence of monocytes. J. Infect. Dis. 187, 710-713. doi: 10.1086/368334

Pahl, H. L., Krauss, B., Schulze-Osthoff, K., Decker, T., Traenckner, E. B., Vogt, M., et al. (1996). The immunosuppressive fungal metabolite gliotoxin specifically inhibits transcription factor NF-kappaB. J. Exp. Med. 183, 1829-1840. doi: 10.1084/jem.183.4.1829

Ptachcinski, R. J., Venkataramanan, R., and Burckart, G. J. (1986). Clinical pharmacokinetics of cyclosporin. Clin. Pharmacokinet. 11, 107-132. doi: 10.2165/00003088-198611020-00002

Reese, T. A., Liang, H. E., Tager, A. M., Luster, A. D., Van Rooijen, N., Voehringer, D., et al. (2007). Chitin induces accumulation in tissue of innate immune cells associated with allergy. Nature 447, 92-96. doi: 10.1038/nature05746

Rether, J., Serwe, A., Anke, T., and Erkel, G. (2007). Inhibition of inducible tumor necrosis factor-alpha expression by the fungal epipolythiodiketopiperazine gliovirin. Biol Chem. 388, 627-637. doi: 10.1515/BC.2007.066

Richter, S., Cormican, M. G., Pfaller, M. A., Lee, C. K., Gingrich, R., Rinaldi, M. G., et al. (1999). Fatal disseminated Trichoderma longibrachiatum infection in an adult bone marrow transplant patient: species identification and review of the literature. J. Clin. Microbiol. 37, 1154-1160.

Roberts, D. P., and Lumsdem, R. D. (1990). Effect of extracellular metabolites from Giocladium virens on germination of sporangia and mycelial growth of Phytium ultimum. Phytopathology 80, 461-465. doi: 10.1094/Phyto-80-461

Rodríguez, M. A., Cabrera, G., and Godeas, A. (2006). Cyclosporine A from a nonpathogenic Fusarium oxysporum suppressing Sclerotinia sclerotiorum. J. Appl. Microbiol. 100, 575-586. doi: 10.1111/j.1365-2672.2005.02824.x

Roossinck, M. J., and García-Arenal, F. (2015). Ecosystem simplification, biodiversity loss and plant virus emergence. Curr. Opin. Virol. 10, 56-52. doi: 10.1016/j.coviro.2015.01.005

Rop, O., Mlcek, J., and Jurikova, T. (2009). Beta-glucans in higher fungi and their health effects. Nutr. Rev. 67, 624-631. doi: 10.1111/j.1753-4887.2009.00230.x

Rovira, P., Mascarell, L., and Truffa-Bachi, P. (2000). The impact of immunosuppressive drugs on the analysis of T cell activation. Curr. Med. Chem. 7, 673-692. doi: 10.2174/0929867003374778

Sakamoto, H., Egashira, S., Saito, N., Kirisako, T., Miller, S., Sasaki, Y., et al. (2015) Gliotoxin suppresses NF-kB activation by selectively inhibiting linear ubiquitin chain assembly complex (LUBAC). ACS Chem. Biol. 10, 675-681. doi: $10.1021 / \mathrm{cb} 500653 \mathrm{y}$

Scharf, D. H., Brakhage, A. A., and Mukherjee, P. K. (2016). Gliotoxin - bane or boon? Environ. Microbiol. 18, 1096-1109. doi: 10.1111/1462-2920.13080

Scheepmaker, J. W. A., and Butt, T. M. (2010). Natural and released inoculum levels of entomopathogenic fungal biocontrol agents in soil in relation to risk assessment and in accordance with EU regulations. Biocontrol Sci. Technol. 20, 503-552. doi: 10.1080/09583150903545035

Schlam, D., Canton, J., Carreño, M., Kopinski, H., Freeman, S. A., and Grinstein, S. (2016). Gliotoxin suppresses macrophage immune function by subverting phosphatidylinositol 3,4,5-triphosphate homeostasis. Mbio 7:e02242. doi: 10.1128/mBio.02242-15

Schulz, T., Senkpiel, K., and Ohgke, H. (2004). Comparison of the toxicity of reference mycotoxins and spore extracts of common indoor moulds. Int. J. Hyg. Environ. Health 207, 267-277. doi: 10.1078/1438-4639-00282

Shin, S. H., Ponikau, J. U., Sherris, D. A., Congdon, D., Frigas, E., and Homburger, H. A. (2004). Chronic rhinosinusitis: an enhanced immune response to ubiquitous airborne fungi. J. Allergy Clin. Immunol. 114, 1369-1375. doi: 10.1016/j.jaci.2004.08.012

Singh, N., Chang, F. Y., Gayowski, T., and Marino, I. R. (1997). Infections due to dematiaceous fungi in organ transplant recipients: case report and review. Clin. Infect. Dis. 24, 369-374. doi: 10.1093/clinids/24.3.369

Sorrell, T. C., and Chen, S. C. (2009). Fungal-derived immune modulating molecules. Adv. Exp. Med. Biol. 666, 108-120. doi: 10.1007/978-1-4419-1601-3_9

St Leger, R. J., and Wang, C. (2010). Genetic engineering of fungal biocontrol agents to achieve greater eficacy against insect pests. Appl. Microbiol. Biotechnol. 85, 901-907. doi: 10.1007/s00253-009-2306-Z

Stoeva, A., Harizanova, V., de Lillo, E., Cristofaro, M., and Smith, L. (2012). Laboratory and field experimental evaluation of host plant specificity of Aceria solstitialis, a prospective biological control agent of yellow starthistle. Exp. Appl. Acarol. 56, 43-55. doi: 10.1007/s10493-011-9497-6

Tahat, M. M., Sijam, K., and Othman, R. (2010). Mycorrhizial fungi as a biocontrol agent. Plant Pathol. J. 9, 198-107. doi: 10.3923/ppj.2010.198.207

Tartar, A., Shapiro, A. M., Schar, D. W., and Boucias, D. G. (2005). Differential expression of chitin synthase (CHS) and glucan synthase (FKS) genes correlates with the formation of a modified thinner cell wall in in vivo-produced Beauveria bassiana cells. Mycopathologia 160, 303-314. doi: 10.1007/s11046-0050134-y

Teixeira, P. J., Thomazella, D. P., and Pereira, G. A. (2015). Time for chocolate: current understanding and new perspectives on Cacao Witches' Broom Disease Research. PLoS Pathog. 11:e1005130. doi: 10.1371/journal.ppat.1005130

Thakore, Y. (2006). The biopesticide market for global agricultural use. Ind. Biotechnol. 23, 192-108. doi: 10.1089/ind.2006.2.194

Thell, K., Hellinger, R., Schabbauer, G., and Gruber, C. W. (2014). Immunosuppressive peptides and their therapeutic applications. Drug Discov. Today 19, 645-653. doi: 10.1016/j.drudis.2013.12.002

Trabelsi, S., Hariga, D., and Khaled, S. (2010). First case of Trichoderma longibrachiatum infection in a renal transplant recipient in Tunisia and review of the literature. Tunis Med. 88, 52-57.

Tsunawaki, S., Yoshida, L. S., Nishida, S., Kobayashi, T., and Shimoyama, T. (2004). Fungal metabolite gliotoxin inhibits assembly of the human respiratory burst nadph oxidase. Infect. Immun. 72, 3373-3382. doi: 10.1128/IAI.72.6.3373-3382.2004

US Environmental Protection Agency (EPA) (1996). OPPTS 885.3000 BackgroundMammalian Toxicity/pathogenicity/infectivity. (Accessed December 10, 2016)

Van Dyken, S. J., Garcia, D., Porter, P., Huang, X., Quinlan, P. J., Blanc, P. D., et al. (2011) Fungal chitin from asthma-associated home environments induces eosinophilic lung infiltration. J. Immunol. 187, 2261-2267. doi: 10.4049/jimmunol.1100972

Vargas, W. A., Mukherjee, P. K., Laughlin, D., Wiest, A., Moran-Diez, M. E., and Kenerley, C. M. (2014). Role of gliotoxin in the symbiotic and pathogenic interactions of Trichoderma virens. Microbiology 160, 2319-2330. doi: 10.1099/mic.0.079210-0

Vázquez, M. M., César, S., Azcón, R., and Barea, J. M. (2000). Interactions between arbuscular mycorrhizal fungi and other microbial inoculants (Azospirillum, Pseudomonas, Trichoderma) and their effects on microbial population and 
enzyme activities in the rhizosphere of maize plants. Appl. Soil Ecol. 15, 261-272. doi: 10.1016/S0929-1393(00)00075-5

Wang, C., Fan, M., Li, Z., and Butt, T. M. (2004). Molecular monitoring and evaluation of the application of the insect-pathogenic fungus Beauveria bassiana in southeast china. J. Appl. Microbiol. 96, 861-870. doi: 10.1111/j.1365-2672.2004.02215.x

Wani, Z. A., Ashraf, N., Mohiuddin, T., and Riyaz-Ul-Hassan, S. (2015). Plant-endophyte symbiosis, an ecological perspective. Appl. Microbiol. Biotechnol. 99, 2955-2965. doi: 10.1007/s00253-0156487-3

Ward, M. D., Chung, Y. J., Copeland, L. B., and Doerfler, D. L. (2011). Allergic responses induced by a fungal biopesticide Metarhizium anisopliae and house dust mite are compared in a mouse model. J. Toxicol. 2011:360805. doi: $10.1155 / 2011 / 360805$

Westwood, G. S., Huang, S. W., and Keyhani, N. O. (2005). Allergens of the entomophatogenic fungus Beauveria bassiana. Clin. Mol. Allergy 3, 1. doi: 10.1186/1476-7961-3-1

Westwood, G. S., Huang, S. W., and Keyhani, N. O. (2006). Molecular and immunological characterization of allergens from the entomopathogenic fungus Beauveria bassiana. Clin. Mol. Allergy 22, 4-12. doi: 10.1186/1476-7961-4-12

Whipps, J. M. (2001). Microbial interactions and biocontrol in the rhizosphere. J. Exp. Bot. 52, 487-411. doi: 10.1093/jexbot/52.suppl_ 1.487
Yoshida, K., Schuenemann, V. J., Cano, L. M., Pais, M., Mishra, B., Sharma, R., et al. (2013). The rise and fall of the Phytophthora infestans lineage that triggered the Irish potato famine. Elife 2:e00731. doi: 10.7554/eLife.00731

Yoshida, L. S., Abe, S., and Tsunawaki, S. (2000). Fungal gliotoxin targets the onset of superoxide-generating NADPH oxidase of human neutrophils. Biochem. Biophys. Res. Commun. 268, 716-723. doi: 10.1006/bbrc.2000.2192

Zeilinger, S., Gruber, S., Bansal, R., and Mukherjee, P. K. (2016). Secondary metabolism in Trichoderma - Chemistry meets genomics. Fung. Biol. Rev. 30, 74-90. doi: 10.1016/j.fbr.2016.05.001

Zimmermann, G. (2007). Review on safety of the entomopathogenic fungi Beauveria bassiana and Beauveria brongniartii. Biocontrol Sci. Technol. 17, 553-596. doi: 10.1080/09583150701309006

Conflict of Interest Statement: The authors declare that the research was conducted in the absence of any commercial or financial relationships that could be construed as a potential conflict of interest.

Copyright (c) 2017 Konstantinovas, de Oliveira Mendes, Vannier-Santos and Lima-Santos. This is an open-access article distributed under the terms of the Creative Commons Attribution License (CC BY). The use, distribution or reproduction in other forums is permitted, provided the original author(s) or licensor are credited and that the original publication in this journal is cited, in accordance with accepted academic practice. No use, distribution or reproduction is permitted which does not comply with these terms. 